\title{
PHYTOCHEMICAL SCREENING AND ANTIBACTERIAL ACTIVITY OF Acorus calamus L. EXTRACTS
}

\author{
Bayyinatul Muchtaromah*1, Alfiah Hayati $^{2}$, Erna Agustina ${ }^{3}$
}

Received : February 22, 2019

Accepted : April 05, 2019

DOI: 10.15575/biodjati.v4i1.4235

${ }^{1,3}$ Department of Biology, Faculty of Science and Technology, Universitas Islam Negeri (UIN) Maulana Malik Ibrahim Malang, Indonesia. Jl. Gajayana 50, Malang, 65144, Jawa Timur, Indonesia. Phone: +62341558933, +6281231842316, Fax: +62341558933

${ }^{2}$ Department of Biology, Faculty of Science and Technology, Universitas Airlangga, Kampus C, Mulyorejo, Surabaya, 60115, Phone 031-5936501, Fax : 031-5936502.

e-mail:

*1bayyinatul@bio.uin-malang.ac.id

2alfiah-h@fst.unair.ac.id

3ernaagustina78@yahoo.com

*Corresponding author

\begin{abstract}
Staphylococcus aureus and Escherichia coli are among the most common species of gram-positive and gram-negative bacteria, which cause vaginitis, in infertilewomen. The Calamus rhizome (Acorus calamus L.) is an Indonesian plant that has antibacterial properties that can be used to treat vaginitis and increase fertility. The aim of this study was to determine the phytochemical and antibacterial activity of the calamus rhizoma in polar, semi-polar and non-polar solvents in the growth of $S$. aureus and E. coli. The antibacterial activity test was in the form of inhibitory test using the Kirby-Bauer, Minimum Inhibition Concentration (MIC) and Minimum Bactericidal Concentration $(M B C)$ by microdilution method with multilevel dilution (concentrations $50 ; 25 ; 12.5 ; 6.25 ; 3.13 ; 1.56 ; 0.78$; and $0.39 \%$ ). The screening results showed that ethanol and $n$-hexane extract contained alkaloids and triterpenoids, while chloroform extract was only triterpenoid. Chloroform extract produced the largest inhibition zone diameter of S. aureus and E. coli (7.26 and $3.28 \mathrm{~mm})$, followed by ethanol extract (5.90 and $3.07 \mathrm{~mm}$ ) and $n$-hexane extract (5.33 and $2.95 \mathrm{~mm}$ ). The concentrations of 0.39 and $0.78 \%$ were the values of $M I C$ and $M B C$ for all three extracts, indicating that the extract of the calamus rhizome with several solvents in this study had the same antibacterial activity.
\end{abstract}

Keywords: Acorus calamus, antibacterial activity, phytochemical screening

\section{Citation}

Muchtaromah, B., Hayati, A. \& Agustina, E. (2019). Phytochemical Screening and Antibacterial Activity of Acorus calamus L. Extracts. Jurnal Biodjati, 4(1), 68-78

\section{INTRODUCTION}

Staphylococcus aureus is one of the normal flora in the female reproductive tract. Escherichia coli can be a pathogen when it reaches tissues outside the digestive tract. Both contribute to reproductive tract infections. Under certain conditions, the normal flora can cause disease or infection, when the substrate changes or bacteria move into suitable habitat (Conway \& Cohen, 2015). Pino et al. (2019) and Bhandari \& Prabha (2015) report that predominant vaginal normal flora is lactobacilli (95\%), besides that there is also a small amount $(5 \%)$ of wide variations of $S$. aureus and E. coli. If the Lactobacillus population decrease, the population of other bacteria such as $S$. aureus and E. coli will increase and can become pathogens in the reproductive tract.

One infection caused by $S$. aureus and E. coli is vaginitis. Vaginitis is the contamination of the female reproductive tract. The number of bacteria in the normal vaginal ecosystem is $10^{5}$ to $10^{6} /$ gram vaginal secretions, 


\section{JURNAL BIDDJATI}

http://journal.uinsgd.ac.id/index.php/biodjati

but in reproductive tract infections increases $10^{9}-10^{10}$ gram which can cause infertility (Orji, 2015). Orji (2015) reported that $S$. aureus had a prevalence rate (18.6\%), whereas Isibor et al. (2011) revealed that $E$. coli had a prevalence rate of $13.1 \%$ in cases of vaginitis.

Acorus calamus L. is one type of medicinal plant with many benefits. One of commercial herbal products that have properties to improve fertility and overcome infertility problems is "Subur Kandungan" herbs. The main ingredient of this product is calamus rhizome, containing approximately around $12 \%$ and other components up to $100 \%$.

Anisah et al. (2014) reported ethanol and water extracts of calamus rhizoma containing alkaloids, flavonoids and polyphenols. Methanolic extract of Acorus calamus showed the presence of glycosides, carbohydrates, phenolic compounds, saponins, alkaloids, flavonoids, tannins, saponins, steroids and triterpenoids (Mamta \& Jyoti, 2012). The antimicrobial activity of $A$. calamus is related to A- and B-asarones contained in rhizome and leaf extracts (Devi \& Ganjewala, 2009).

Previous research, ethanol extract of calamus rhizoma with a concentration of $100 \%$ inhibited the growth of $S$. aureus $(2.75$ $\mathrm{cm} /$ very strong) and E. coli $(2.98 \mathrm{~cm} /$ very strong), while water extract inhibited $S$. aureus $(1.53 \mathrm{~cm} /$ medium $)$ and $E$. coli $(1.03 \mathrm{~cm} /$ medium) (Anisah et al., 2014). Similar studies but carried out on other plants also produce varying antibacterial activity. Rahman et al. (2012) showed that chloroform extract of Phyllanthus niruri produced antibacterial activity against $S$. aureus and $E$. coli higher than ethyl acetate extract which is $26 \mathrm{~mm}$ and 6.6 $\mathrm{mm}$ respectively. At last, Ningsih et al. (2016) stated that chloroform solvents in soursop leaves had a higher ability to inhibit $E$. coli than n-hexane (8.34 and $3.45 \mathrm{~mm}$ ).

According to the background above, it was essential to look for phytochemical content and the best organic solvent of calamus rhizoma extract in inhibiting the growth of $S$. aureus and E. coli considering that these two bacteria were normal flora in the reproductive and digestive tract with a high prevalence in cases of vaginitis. The results of this study can be trigger for the calamus rhizoma certification process, as one of component of Madurese herbal medicine which can overcome infertility. Therefore, traditional medicine product could be accepted in the modern medical system for enhancing public health

\section{MATERIALS AND METHODS}

The type of research was experimental research. Extraction of the active component of calamus rhizoma using maceration method with three different kinds of solvents which were different in polarity, including ethanol, chloroform and n-hexane. Antibacterial activity test of $S$. aureus and E. coli using the Kirby Bauer method, to determine the diameter of bacterial inhibition and liquid microdilution to determine Minimum Inhibition Concentration (MIC) and Minimum Bactericidal Concentration $(\mathrm{MBC})$.

Materials came from calamus rhizoma (A. calamus) which obtained from the Balai Materia Medika, Indonesia. All chemicals from Merck Ltd and the culture of bacteria from the Microbiology Laboratory, Faculty of Medicine, Universitas Brawijaya, Indonesia.

Making extracts using $100 \mathrm{~g}$ of calamus rhizoma powder mixed with ethanol (polar), chloroform (semi-polar) and n-hexane (nonpolar) solvents of about $400 \mathrm{ml}$ (1:4) respectively. The object was soaked and stirred until smooth, after that shaked for 24 hours, $120 \mathrm{rpm}$. The filtrate was obtained by filtration, and then the pulp was macerated again with the same solvent and concentrated using 


\section{JURNAL BIDDJATI}

http://journal.uinsgd.ac.id/index.php/biodjati

a rotary evaporator at a temperature of $50^{\circ} \mathrm{C}$ (Muchtaromah et al., 2011).

Phytochemical screening (alkaloids, flavonoids, terpenoids, saponins, tannins, steroid) based on the method of Tiwari et al. (2011) and Ibironke et al. (2010). The bacterial inhibitory zone test used the Kirby Bauer method with $100 \%$ calamus rhizome extract. MIC and MBC tests used a series of dilutions of $50,25,12.5,6.25,3.13,1.56$, 0.78 and $0.39 \%$. The pure culture of bacteria (stock) was inoculated in $5 \mathrm{ml}$ Agar Nutrient media then incubated for $24 \mathrm{~h}$ in an incubator at $37^{\circ} \mathrm{C}$. The formed colonies showed bacterial growth. Bacteria that have been recultured were taken one streak and added $0.9 \%$ sterile $\mathrm{NaCl}$ as much as $5 \mathrm{~mL}$ (Vineetha et al., 2015). The bacteria solution was compared with the McFarland 0.5 solution. If the turbidity of the bacterial suspension test was the same as turbidity in McFarland 0.5 solution, the concentration of bacterial suspension is $10^{8} \mathrm{CFU} / \mathrm{mL}$ (Fatisa, 2013).

Kirby Bauer method used paper discs (6 mm diameter). $200 \mu \mathrm{L}$ of bacterial suspension was put into sterile Petri dishes, then $20 \mathrm{~mL}$ of Mueller Hinton Agar (MHA) media was inserted, and allowed to solidify. The media was divided into three areas for laying paper discs and did the replication three times. A sterile disc was soaked with $100 \%$ extracts, for one hour. A positive control using clindamycin and negative control using DMSO. The disc paper was placed on the surface of bacterial media and incubated at $37^{\circ} \mathrm{C}$ for $24 \mathrm{~h}$. After $24 \mathrm{~h}$, the presence of clear zones around the paper disk was observed and measured using a caliper. The liquid microdilution method used 30 microplate wells for each type of bacteria (three wells for material control, three wells for microbial control and 24 wells for test treatment) (Vineetha et al., 2015).

MIC was a minimal concentration of calamus rhizoma extract which could inhibit the growth of test bacteria, while MBC was a minimum concentration capable of killing bacteria, which was indicated by the absence of colonies or the number of colonies $<0.1 \%$ of the Original Inoculum (OI) (Winarsih et al., 2011).

Bacterial suspension of $10^{6} \mathrm{CFU} / \mathrm{mL}$ was incubated in Nutrient media for $24 \mathrm{~h}$, then the turbidity of each level was observed. MIC values were determined visually from each concentration which had clarity compared to bacterial control. Then, confirmed the amount of MBC by planting each concentration in solid media to find out the number of colonies (Vineetha et al., 2015). Counting of bacteria number used the stereomicroscope with APD colony counter. The data obtained in the form of inhibitory zone diameter, MIC value, MBC value and total bacterial colonies were analyzed by descriptive qualitatively.

\section{RESULTS AND DISCUSSION}

\section{The Yield of Calamus Rhizoma Extract}

The extraction results of several organic solvents produced different yield, colors, and textures (Table 1).

Ethanol produced the highest yield (7.8 g) followed by chloroform ( $3.3 \mathrm{~g})$ and n-hexane $(2.4 \mathrm{~g})$. The reason due to ethanol was a polar solvent, and perhaps the calamus rhizoma contained more polar compounds than non-polar compounds. Polarity level of different solvents produced varied colors and textures. Vargas et al. (2016) stated that the yield data for each solution showed a variety of colors, textures and quantities, because of the differences in the active compounds that were successfully extracted, even though the extracted samples came from the same material. 


\section{JURNAL BIDDJATI}

http://journal.uinsgd.ac.id/index.php/biodjati

Table 1. Yield, color, texture and weight of calamus rhizoma extract

\begin{tabular}{cccccc}
\hline No & \multirow{2}{*}{ Solvent } & Color & Texture & $\begin{array}{c}\text { Extract Weight } \\
(\mathrm{g})\end{array}$ & Yield $(\%)(\mathrm{w} / \mathrm{w})$ \\
\hline 1. & Ethanol p.a & Greenish brown & Porridge & 7.8 & 7.8 \\
2. & Chloroform p.a & Reddish brown & Porridge & 3.3 & 3.3 \\
3. & N-Hexane p.a & Blackish brown & Concentrated liquid & 2.4 & 2.4 \\
\hline
\end{tabular}

\section{Qualitative Phytochemical Screening}

Phytochemical testing of the extract was the first step that gave an overview of classes of secondary metabolite compounds contained in each extract (Table 2).

The phytochemical test showed that ethanol and n-hexane extract contained alkaloid and triterpenoid, the extract n-hexane contained relatively high triterpenoid and the chloroform extract contained triterpenoids only. According to Imam et al. (2013), photochemical studies have reported that ethanol extract of calamus rizhome comprised of glycosides, flavonoids, saponins, tannins, polyphenolic compounds, mucilage, volatile oil and bitter principle. This plant has been reported for the presence of glucoside, alkaloid and essential oil containing calamen, clamenol, calameon, asarone and sesquiterpenes. It also contained a bitter glycoside named aco- rine along with eugenol, pinene and camphene in various solvents (Chandra \& Prasad, 2017). Ethanol was a polar solvent that attract most of the active polar compounds and cannot draw semi-polar and non-polar active compounds. Anisah et al. (2014) reported that the ethanol extract of calamus rhizoma gave positive results for alkaloid compounds, flavonoids and polyphenols. Chloroform was a semi-polar solvent that can extract phenol, terpenoid, alkaloid, aglycone and glycoside compounds (Akhtar et al., 2015). The n-hexane solvent was non-polar which attracted to most non-polar compounds. Hartati (2012) reported that the calamus rhizome n-hexane extract contained essential oils with beta-asarone main compounds.

Table 2. Phytochemical screening of calamus rhizome extract

\begin{tabular}{ccccc}
\hline \multirow{2}{*}{ Phytochemical } & Reagen test & \multicolumn{3}{c}{ Extracts } \\
\cline { 3 - 5 } & Dragendorff & Ethanol & Chloroform & n-hexane \\
\hline \multirow{2}{*}{ Alkaloid } & Mayer & + & - & + \\
Flavonoid & Wilstater & + & - & + \\
Triterpenoid & Lieberman-Burchard & + & + & ++ \\
Steroid & Lieberman-Burchard & - & - & - \\
Saponin & Forth & - & - & - \\
Tannin & $F_{3}$ & - & - & - \\
\hline
\end{tabular}

$(+++)$ very highly present, $(++)$ highly present, $(+)$ present, $(-)$ not present 


\section{JURNAL BIDDJATI}

http://journal.uinsgd.ac.id/index.php/biodjati

\section{Antibacterial Activity of Calamus Rhizo- ma Extract in Several Solvents Inhibitory Zone Diameter of Calamus Rhi- zoma Extract}

The results showed that calamus rhizoma extract had inhibitory zone activity against $S$. aureus and E. coli. The presence of a clear zone around the disc paper showed inhibitory activity (Figures $1 \& 2$ ).

This research showed that the type of solvent extracted from the calamus rhizoma had an influence on the average diameter of the inhibition zone both for $S$. aureus and $E$. coli. The highest results of $S$. aureus inhibition zone diameter were chloroform extract (7.26 $\pm 1.45 \mathrm{~mm} /$ strong), followed by ethanol extract $(5.90 \pm 1.11 \mathrm{~mm} /$ medium $)$ and $n$-hexane extract $(5.33 \pm 0.44 \mathrm{~mm} /$ medium). The results of the inhibition zone diameter on $E$. coli from the highest were chloroform extract (3.28 \pm $0.15 \mathrm{~mm} /$ medium), ethanol extract (3.07 \pm $0.37 \mathrm{~mm} / \mathrm{medium})$ and $\mathrm{n}$-hexane extract (2.95 $\pm 0.22 \mathrm{~mm} /$ weak) (Table 3).
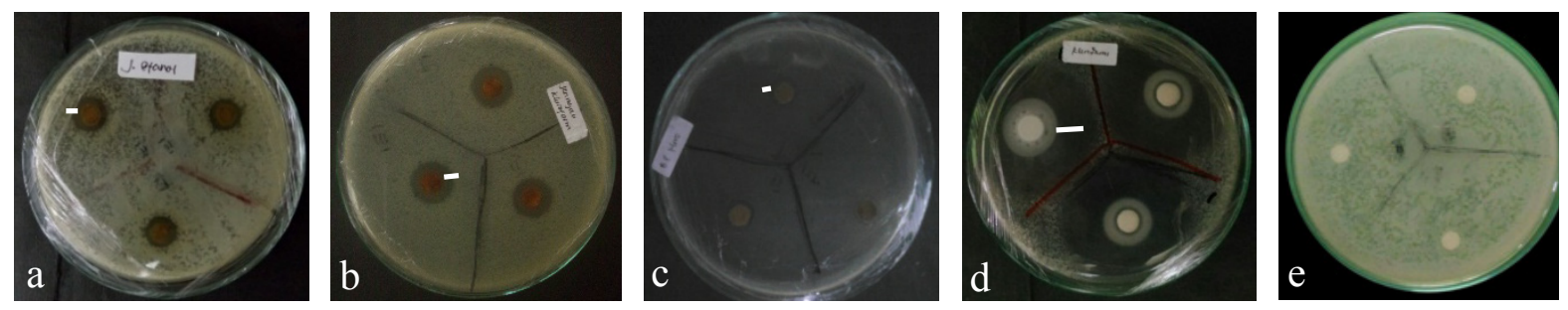

Figure 1. Results of inhibitory zone diameter for Staphylococcus aureus, (a) ethanol extract; (b) chloroform extract; (c) n-hexane extract; (d) clindamycin; and (e) DMSO
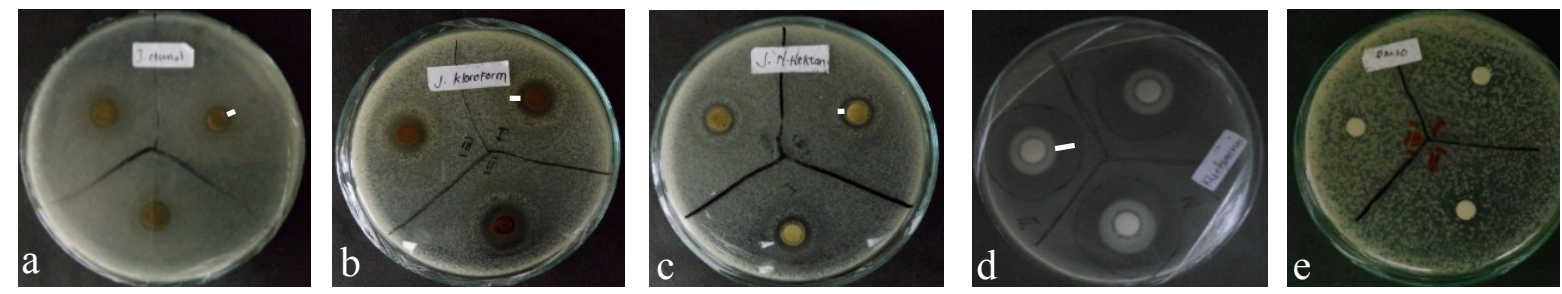

Figure 2. Results of inhibitory zone diameter on Escherichia coli (a) ethanol extract; (b) chloroform extract; (c) n-hexane extract; (d) clindamycin; and (e) DMSO

Table 3. The diameter of the inhibition zone of calamus rhizoma extracts against $S$. aureus and E. coli

Bacterial Species

\begin{tabular}{|c|c|c|c|c|}
\hline \multirow{2}{*}{ Type of Extract } & \multicolumn{2}{|c|}{ Staphylococcus aureus } & \multicolumn{2}{|c|}{ Escherichia coli } \\
\hline & $\begin{array}{c}\text { Diameter }(\mathrm{mm}) \\
\pm \mathrm{SD}\end{array}$ & $\begin{array}{c}\text { Category (Pan et } \\
\text { al., 2009) }\end{array}$ & $\begin{array}{c}\text { Diameter }(\mathrm{mm}) \pm \\
\text { SD }\end{array}$ & $\begin{array}{c}\text { Category (Pan et } \\
\text { al., 2009) }\end{array}$ \\
\hline Ethanol (T1) & $5.90 \pm 1.11$ & Moderate & $3.07 \pm 0.37$ & Moderate \\
\hline Chloroform (T2) & $7.26 \pm 1.45$ & Strong & $3.28 \pm 0.15$ & Moderate \\
\hline n-Heksana (T3) & $5.33 \pm 0.44$ & Moderate & $2.95 \pm 0.22$ & Weak \\
\hline Clindamycin $(\mathrm{C}+)$ & $37.08 \pm 0.50$ & Strong & $30.29 \pm 1.78$ & Strong \\
\hline $\operatorname{DMSO}(\mathrm{C}-)$ & 0 & - & 0 & - \\
\hline
\end{tabular}




\section{Jurnal Biodjati 4(1):68-78, May 2019 \\ JURNAL BIDDJATI}

http://journal.uinsgd.ac.id/index.php/biodjati

These results indicated that the diameter of $S$. aureus inhibition zone was higher than E. coli. Clindamycin as a positive control resulted in a greater inhibition zone compared to calamus rhizome extract, namely $S$. aureus $(37.08 \pm 0.50 \mathrm{~mm} / \mathrm{strong})$ and $E$. coli $(30.29 \pm$ $1.78 \mathrm{~mm} /$ strong). DMSO as a negative control did not indicate the clear zone around the disc paper, proving that DMSO 100\% solvent had no antibacterial activity.

Unlike the previous studies, the inhibition zone test for Candida albicans produced the highest value on ethanol extract (3.72 $\mathrm{mm} /$ moderate) followed by $\mathrm{n}$-hexane (3.32 $\mathrm{mm} /$ medium) and chloroform (2.22 $\mathrm{mm} /$ weak) (Muchtaromah et al., 2017). According to Chandra \& Prasad (2017), differences in solvents could affect the results of phytochemical compounds drawn during extraction while the number and type of active compounds influenced the biological activity.

In contrast to the study of Shreelaxmi et al. (2018), reported that ethyl acetate as the best solvent for the extraction of active ingredients (A- and B-asarone) from the rhizomes and leaves of $A$. calamus compared to other waters. Solutions such as methanol, ethanol and hexane used in most previous studies were appropriate for the extraction of active ingredients. A- and B-asarones found in leaf, root and rhizome tissues were responsible for antimicrobial activity of $A$. calamus.

Here are some studies that use several kind of solvents and their antibacterial activity. Singh et al. (2011) study revealed that methanol extract from A. calamus showed inhibitory action against strains of Salmonella typhi, Pseudomonas aeruginosa, Klebsiella pneumoniae and Staphylococcus aureus. The third fraction of crude methanol extract showed the highest inhibition of $S$. aureus, $E$. coli and the fraction was confirmed as B-asarone. B-asarone compounds from A. calamus have the highest inhibitory effect on E. coli strains at various concentrations. Ethanol and water extracts from the A. calamus also showed inhibitory effects on the above organisms (Manikandan et al., 2010).

According to Balakumbahan et al. (2010), the crude methanol (polar) extract of the $A$. calamus showed a low inhibitory activity against $S$. aureus and E. coli. Devi \& Ganjewala (2009) reported that the ethyl acetate (semi-polar) extract of calamus rhizome did not affect $S$. aureus while in this research ethanol and methanol extracts had anti-bacterial effect on this bacterium. It was suggested that this difference originated from the location where the plant had grown and resulted in gaps in the profile of secondary metabolites that have antibacterial properties (Singh et al., 2011). In addition, geographical, year and season differences also affected the results of extraction, active compounds and radical scavenging activities (Bonilla et al., 2013).

Calamus rhizome recorded a zone of inhibition of the $12.5 \mathrm{~mm}$ Mucur species, while the calamus rhizome oil recorded an inhibitory region of 11.5 and $10.3 \mathrm{~mm}$ for Aspergillus and Penicillium species. Srividya et al. (2014) reported similar findings.

The triterpenoid group was an antibacterial compound, which worked by reacting with transmembrane proteins (porin) on the outer membrane of the bacterial cell wall and forming strong polymeric bonds that caused damage to the porin Tiwari et al. (2011). Alkaloids worked as antibacterial by disrupting the constituent components of peptidoglycan in bacterial cells, therefore the bacterial cell wall layer was not formed intact and caused bacterial cell death (Cushnie et al., 2014).

The difference in active compounds drawn in ethanol, chloroform and n-hexane extracts will affect the ability of the inhibitory zone on $S$. aureus and E. coli. The diameter of 


\section{Jurnal Biodjati 4(1):68-78, May 2019 \\ JURNAL BIODJATI}

http://journal.uinsgd.ac.id/index.php/biodjati

the $S$. aureus inhibition zone was much higher than E. coli. The results of this research indicated that calamus extract could inhibit $S$. aureus better than E. coli (Table 3). The difference in cell wall structure in both types of bacteria caused differences in inhibitory zone activity of calamus rhizome extract (Jawetz et al., 2005), such as peptidoglycan, the number of lipids, crosslinking, enzyme activity, determine penetration, binding and antibacterial activity.

According to Jawetz et al. (2005), the structure of cell walls of gram-positive bacteria was simpler than gram-negative. The construction of single-layered gram-positive cell walls with low lipid levels (1-4\%) made easier for bioactive materials to enter the cell, while the cell wall structure of gram-negative bacteria was more complicated, which consisted of three layers. The outer and middle layer included of lipoprotein and lipopolysaccharide which acted as a barrier to the entry of antibacterial bioactive material, while the inner layer consisted of peptidoglycan with high lipid content (11-12\%). The difference in the structure and components of the cell wall caused E. coli to be more resistant than S.aureus.

\section{Value of Minimum Inhibition Concentra- tion (MIC) and Minimum Bactericidal Concentration (MBC) Calamus Rhizoma Extracts}

In this study, it was necessary to know the minimum concentration of calamus rhizoma extract that could inhibit both test bacteria. MIC was the lowest concentration that inhibits bacterial growth, marked by no turbidity after incubation for 18-24 hours and observed visually (Table 4).

The administration of calamus rhizoma extract started at $0.39 \%$ concentration and $0.78 \%$ produced clear color (no turbidity) which meant that at this concentration $S$. aureus and E. coli bacteria did not grow (Table 4).

Direct observation of the level of turbidity visually (liquid dilution test) for determining MIC is confirmed using the drop plate method (Table 5).

Original inoculum (microbial control) containing the highest number of bacteria compared to the others, namely $S$. aureus $\left(1.59 \times 10^{14} / \mathrm{mL}\right)$, whereas in E. coli $(1.67 \times$ $\left.10^{18} / \mathrm{mL}\right)$. As the increasing of treatment concentration using calamus rhizoma extract was given, the number of bacteria decreased (Table 5).

Table 4. The diameter of the inhibition zone of calamus rhizoma extracts against $S$. aureus and E. coli

\begin{tabular}{|c|c|c|c|c|c|c|}
\hline \multirow{3}{*}{$\begin{array}{l}\text { Treatment (Extract } \\
\text { Concentration, \%) }\end{array}$} & \multicolumn{6}{|c|}{ Turbidity } \\
\hline & \multicolumn{3}{|c|}{ Staphylococcus aureus } & \multicolumn{3}{|c|}{ Escherichia coli } \\
\hline & Ethanol & Cloroform & n-Heksana & Ethanol & Cloroform & n-Heksana \\
\hline Extract Control (100) & +++ & +++ & +++ & +++ & +++ & +++ \\
\hline 50 & +++ & +++ & +++ & +++ & +++ & +++ \\
\hline 25 & +++ & +++ & +++ & +++ & +++ & +++ \\
\hline 12.5 & +++ & +++ & +++ & +++ & +++ & ++ \\
\hline 6.25 & ++ & ++ & ++ & +++ & +++ & + \\
\hline 3.13 & ++ & ++ & ++ & ++ & ++ & + \\
\hline 1.56 & + & + & + & + & + & + \\
\hline 0.78 & + & + & - & + & + & - \\
\hline 0.39 & + & + & - & + & + & - \\
\hline Microbial Control (0) & +++ & +++ & +++ & +++ & +++ & +++ \\
\hline
\end{tabular}

Description: +++: very cloudy, ++: cloudy, +: somewhat cloudy, -: clear 


\section{JURNAL BIDDJATI}

http://journal.uinsgd.ac.id/index.php/biodjati

Table 5. The diameter of the inhibition zone of calamus rhizoma extracts against $S$. aureus and E. coli

\begin{tabular}{ccccccc}
\hline \multirow{2}{*}{$\begin{array}{c}\text { Treatment (Extract } \\
\text { Concentration, \%) }\end{array}$} & \multicolumn{5}{c}{ Average Number of Colonies (CFU/mL) } \\
\cline { 2 - 6 } & Ethanol & Cloroform & n-Hexana & Ethanol & Cloroform & n-Hexana \\
\cline { 2 - 7 } Microbial Control (O) & $1.59 \times 10^{14}$ & $1.59 \times 10^{14}$ & $1.59 \times 10^{14}$ & $1.67 \times 10^{18}$ & $1.67 \times 10^{18}$ & $1.67 \times 10^{18}$ \\
$0.39^{*}$ & $8.00 \times 10^{10}$ & $7.70 \times 10^{10}$ & $7.30 \times 10^{10}$ & $15.9 \times 10^{10}$ & $16.1 \times 10^{10}$ & $13.9 \times 10^{10}$ \\
$0.78^{* *}$ & 0 & 0 & 0 & 0 & 0 & 0 \\
1.56 & 0 & 0 & 0 & 0 & 0 & 0 \\
3.13 & 0 & 0 & 0 & 0 & 0 & 0 \\
6.25 & 0 & 0 & 0 & 0 & 0 & 0 \\
12.50 & 0 & 0 & 0 & 0 & 0 & 0 \\
25 & 0 & 0 & 0 & 0 & 0 & 0 \\
50 & 0 & 0 & 0 & 0 & 0 & 0 \\
Extract Control & 0 & 0 & 0 & 0 & 0 & 0 \\
\hline
\end{tabular}

Description: *Minimum Inhibition Concentration (MIC) **Minimum Bactericidal Concentration (MBC)

The MIC value of the calamus rhizoma extract against $S$. aureus and $E$. coli was $0.39 \%$, with the number of colonies were not significantly difference between the solvents namely ethanol extract at $8.00 \times 10^{10}$ and 15.9 x $10^{10}$, chloroform extract $7.70 \times 10^{10}$ and 16.1 $\times 10^{10}$ and n-Hexane extract at $7.30 \times 10^{10}$ and $13.9 \times 10^{10}$. These results showed that calamus rhizoma extract at $0.39 \%$ concentration was able to inhibit $S$. aureus bacteria better than E. coli. It was proven by a decrease number of $S$. aureus colonies than $E$. coli. The level of $0.78 \%$ was the MBC value of all types of extract for both test bacteria, characterized by the absence of bacterial growth at all (colonies $<0.1 \%$ of the original inoculum). Previous studies showed that concentrations of $0.39 \%$ and $0.78 \%$ were also the MIC and MBC values of calamus rhizoma extract against Candida albicans (Muchtaromah, 2017). Moreover it was known that the calamus rhizome extract effectively inhibited both gram positive and negative bacteria (broad spectrum) and fungi. Marliani (2012) study of the MIC and MBC tests of bangle rhizomes (Zingiber cassumnar Roxb. against $S$. aureus and $E$. coli showed minimum inhibitory conMuchtaromah et al. centrations at a concentration of $1.56 \%$ while the minimum bactericidal level was at a level of $3.125 \%$, indicating the calamus rhizome extract was more effective in inhibiting $S$. aureus and $E$. coli than the bangle rhizome.

Furthermore, Devi \& Ganjewala (2009) reported the antimicrobial activity of rhizome and leaf extracts of $A$. calamus with different solvents, namely petroleum ether, chloroform, hexane, and ethyl acetate. Ethyl acetate extract of rhizomes and leaves produced the most considerable antifungal activity with inhibition zone diameters ranging between 20 28 and $18-25 \mathrm{~mm}$, and anti-yeast action with inhibition zone diameters ranging between 22-25 and 20-23 mm respectively. The MIC of rhizome and leaf extract for antifungal activity was $2-4 \mathrm{mg} / \mathrm{mL}$, except for $P$. chrysogenum whereas for yeast it was relatively higher, 4-5 and $6-8 \mathrm{mg} / \mathrm{mL}$. The MIC value for antibacterial activity was relatively very high $\sim 16-42$ $\mathrm{mg} / \mathrm{mL}$. A-asarone and B-asarone produced robust antimicrobial activity against fungi and yeast compared to rhizome and leaf extracts. This study informed that rhizome and leaf extracts of $A$. calamus must have active compounds A- and B-asarones which were 


\section{Jurnal Biodjati 4(1):68-78, May 2019 \\ JURNAL BIDDJATI}

http://journal.uinsgd.ac.id/index.php/biodjati

responsible for the antimicrobial activity. The rhizome and leaf extract in this study had no antibacterial activity except for $E$. coli.

Available reports showed that the antimicrobial properties of plant parts vary depend on solvent type. Dichloromethane and ethanol extracts of $A$. calamus rhizome had been reported to show substantial antifungal activity. The ethanol extract of $A$. calamus inhibited clinical isolates of $C$. albicans. Based on some previous studies it was known that the difference in effectiveness (MIC value) was partly due to the type of solvent used for extraction, parts of plants and differences in climate and geography. Differences in morphology and constitution of cell walls of microorganisms affected the sensitivity to extract (Balakumbahan et al., 2010).

Based on the results, it can be concluded that ethanol and n-hexane extract contained alkaloids and triterpenoids, while chloroform extract was only triterpenoid. The calamus rhizome extract had antibacterial activity against $S$. aureus and E. coli. Chloroform extract produced the highest inhibition zone diameters $(7.26 \mathrm{~mm}$ and $3.28 \mathrm{~mm})$, followed by ethanol extract $(5.90 \mathrm{~mm}$ and 3.07 $\mathrm{mm}$ ) and n-hexane extract $(5.33 \mathrm{~mm}$ and 2.95 $\mathrm{mm}$ ). The concentration of MIC and MBC were $0.39 \%$ and $0.78 \%$ for all three extracts, indicating the extracts of Acorus calamus rhizomes with several solvents had almost the same antibacterial activity.

\section{ACKNOWLEDGMENTS}

Authors would like to thank those who contributed directly to the research process and the writing of the manuscript: Mujahidin Ahmad, Erna Agustina, Jujuk Istiwandhani, Intan Fachrunni'am, Lina Ainun Nazilah, Naila Alinnaja, Irsyandi Fathurniawan and Romaidi as head of Biology Department.
Furthermore, we are highly thankful to the research funding of Faculty of Science and Technolgy, Universitas Islam Negeri Maulana Malik Ibrahim Malang 2016.

\section{REFERENCES}

Akhtar, N., Haq, I. \& Mirza, B. (2015) . Phytochemical Analysis and Comprehensive Evaluation of Antimicrobial and Antioxidant Properties of 61 Medicinal Plant Species. Arabian Journal of Chemistry, (11), 1223-1235.

Anisah, Siti, K. \& Ari, H. Y. (2014). Aktivitas antibakteri ekstrak rimpang Jeringau (Acorus calamus L.) terhadap pertumbuhan Staphylococcus aureus dan Escherichia coli. Jurnal Protobiont, 3(3), 1.

Balakumbahan, P., Rajamani, K. \& Kumanan, K. An overview of Acorus calamus. (2010). J Med. Plants Res, 4(25), 27402745.

Bhandari, P. \& Prabha V. (2015). Evaluation of Profertility Effect of Probiotic Lactobacillus plantarum 2621 in a Murine Model. Indian J Med Res, 142, 79-84.

Bonilla, M. P., Salido, S., Sánchez, A., Beek, T. A. \& Altarejos, J. (2013). Effect of Extraction Conditions on the Antioxidant Activity of Olive Wood Extracts. International Journal of Food Science, 1-13.

Chandra, D. \& Prasad, K. (2017). Phytochemicals of Acorus calamus (Sweet flag). Journal of Medicinal Plants Studies, 5(5), 277-281.

Conway, T. \& Cohen, P. S. (2015). Commensal and Pathogenic Escherichia coli Metabolism in the Gut. Microbiol Spectr, 3(3), 1-24.

Cushnie, T. P. M., Cushnie, B. \& Lamb, A. J. (2014). Alkaloids: an Overview of Their Antibacterial, Antibiotic-Enhanc- 


\section{Jurnal Biodjati 4(1):68-78, May 2019 \\ JURNAL BI@DIATI}

http://journal.uinsgd.ac.id/index.php/biodjati

ing and Antivirulence Activities. Int $J$ Antimicrob Agents, 44, 377-386.

Devi, A. \& Ganjewala, D. (2009). Antimicrobial Activity of Acorus calamus (L.) rhizome and leaf extract. Acta Biologicalzegediensis, 53(1), 45-49.

Fatisa, Y. (2013). Daya Antibakteri Estrak Kulit dan Biji Buah Pulasan (Nephelium mutabile) terhadap Staphylococcus aureus dan Escherichia coli secara In Vitro. Jurnal Peternakan, 10(1).

Hartati, S., Soemiati, A. \& Eka, I. A. (2012). Isolasi $\beta$-asaron dari Rimpang Dringo (Acorus calamus Linn.) serta Uji Aktivitas Antimikroba. Jurnal Bahan Alam Indonesia, 8(2), 85.

Ibironke, A. A., Sarah, O. N. \& Adewale, A. (2010). Anti-microbial Activity and Phytochemical Screening of Five Selected Seeds from Nigeria. Int J Biomed Pharm Sci, 4, 104-106.

Imam, H., Riaz Z, Azhar M \& Sofi G, Hussain A. 2013. Sweet flag. An overview. International Journal of Green Pharmacy, 106(67, 65), 148.

Isibor, J. O., Samuel, S. O., Nwaham, C. I., Amanre I. N., Igbinovia, O. \& Akhile, A. O. (2011). Prevalence of Bacterial and Candida albicans Infection Amongst Women Attending Irrua Specialist Teaching Hospital, Irrua, Nigeria. African Journal of Microbiology Research, 5(20).

Jawetz, E., Melnick, J. L. \& Adelberg, E. A. (2005). Mikrobiologi untuk Profesi Kesehatan (Review of Medical Microbiology) Diterjemahkam oleh H. Tomang (pp. 317-318). EGC: Jakarta.

Mamta, S. \& Jyoti, S. (2012). Phytochemical Screening of Acorus calamus and Lantana camara. International Research Journal of Pharmacy, 3(5), 324-326.

Manikandan, S., Devi, R. S., Srikumar, R.,
Thangaraj, R., Ayyappan, R., Jegadeesh R., et al. In - Vitro Antibacterial Activity of Aqueous and Ethanolic Extracts of Acorus calamus. (2010). Int J Appl Biol Pharm Technol, 1, 1072-1075.

Marliani, L. (2012). Aktivitas Antibakteri dan Telaah Senyawa Komponen Minyak Atsiri Rimpang Bangle (Zingiber cassumunar Roxb.). Prosiding SNaPP: Sains, Teknologi dan Kesehatan, 3(1).

Muchtaromah, B., Kiptiyah, K. \& Ad, T. K. (2011). Transaminase Enzyme and Liver Histological Profile of Mice Administered Extract of Pegagan (Centella asiatica (L.) Urban. Media Peternakan, 34, 88-92.

Muchtaromah, B., Ahmad, M., Sabdoningrum, E. K., Afifah, Y.M. \& Azzahra, V.L. (2017). Phytochemicals, Antioxidant and Antifungal Properties of Acorus calamus, Curcuma mangga and Allium sativum in The Veterinary Medicine International Conference, $\mathrm{KnE}$ Life Sciences, 93-104.

Orji, N. M. (2015). Reproductive Tract Infections Among Females In Ihiala Local Government Area, Anambra State, Nigeria. International Journal of Scientific Engineering and Applied Science (USEAS), 1(3).

Pan, X., F. Chen, T. Wu, H. Tang \& Z. Zhao. (2009). The Acid, Bile Tolerance and Antimicrobial Property of Lactobacillus acidophilus NIT. Journal Food Control, 20, 598-602.

Pino, A., Bartolo, E., Caggia, C., Cianci, A. \& Randazzo, C.L. (2019). Detection of Vaginal Lactobacilli as probiotic candidates. Scientific RepoRts (9)3355.

Rahman, D. T., Sutrisna, E.M., Candrasari, Anika. (2012). Uji Efek Antibakteri Ekstrak Etil Asetat dan Kloroform Meniran (Phyllanthus niruri Linn) ter- 


\section{Jurnal Biodjati 4(1):68-78, May 2019 \\ JURNAL BI@DJATI}

http://journal.uinsgd.ac.id/index.php/biodjati

hadap Pertumbuhan Bakteri Staphylococcus aureus ATCC 6538 dan Escherichia coli ATCC 11229 Secara In Vitro. Biomedika, 4(2).

Shreelaxmi, Sharanagouda, H., Ramachandra, C. T., Roopa, R. S. \& Hanchinal, S. G. (2018). Antimicrobial Activity of Supercritical Fluid Extracted Acorus calamus Oil Against Different Microbes. Journal of Pharmacognosy and Phytochemistry, 7(3), 2836-2840.

Srividya, G. \& Adilaxmamma, K. (2014). Ameliorative Effect of Acorus calamus in Drug Induced Hepatotoxicity in Rats. Int. J Sci. Tech, 3(5), 7-9.

Singh, R., Sharma, P. K. \& Malviya, R. (2011). Pharmacological Properties and Ayurvedic Value of Indian Buch Plant (Acorus calamus): A Short Review. Advances in Biological Research, 5(3), 148.

Tiwari, P., Kumar, B., Kaur, M., Kaur, G. \& Kaur, H. (2011). Phytochemical screening and Extraction: A Review. Internationale Pharmaceutica Sciencia, 1(1), 98-106.
Vargas, R. A., Malacara, C. F. P. \& Petricevich, V. L. (2016). Characterization of Chemical Compounds with Antioxidant and Cytotoxic Activities in Bougainvillea $x$ buttiana Holttum and Standl, (var. Rose) Extracts. Antioxidants, 5(45).

Vineetha, N., Vignesh, R. A. \& Sridhar, D. (2015). Preparation, Standardization of Antibiotic Discs and Study of Resistance Pattern for First-Line Antibiotics in Isolates from Clinical Samples. International Journal of Applied Research, 1(11), 624-631.

Winarsih, S., Rita, R. \& Irisda, N. (2011). Hambatan Ekstrak Etanol Gel Lidah Buaya (Aloe vera) Terhadap Pertumbuhan Jamur Candida albicans Isolat Vagina 218: SV Secara In Vitro. Jurnal Penelitian Mahasiswa Program Studi Pendidikan Dokter FKUB. 